\title{
The Effectiveness of Mobile Application of Earthquake and Tsunami Early Warning System in Community Based Disaster Risk Reduction
}

\author{
Andre Kurniawan Pamuji ${ }^{1}$, Rr M I Retno Susilorini2* ${ }^{*}$, Amrizarois Ismail ${ }^{2}$, Ardhito Hayyu Amasto ${ }^{2}$ \\ ${ }^{1}$ Master Program of Environment and Urban Studies, Faculty of Environmental Science and Technology, Soegijapranata Catholic \\ University, Jl. Pawiyatan Luhur IV/1, Bendan Dhuwur, Semarang 50234, Indonesia \\ ${ }^{2}$ Department of Infrastructure and Environmental Engineering, Faculty of Environmental Science and Technology, \\ Soegijapranata Catholic University, Jl. Pawiyatan Luhur IV/1, Bendan Dhuwur, Semarang 50234, Indonesia
}

*Corresponding author: ORCID 0000-0001-8531-7485

\begin{abstract}
Community Based Disaster Risk Reduction (Community Based DRR) needs participatory of the society in disaster prone area to get involved in the process and goals. Saving live and also reducing devastated infrastructures is the highest priority in Early Warning System (EWS) in earthquake and tsunami prone areas. Unfortunately, there is little availability for EWS that is very user-friendly, easy to access, and have local information and content. Hence, this research wants to develop a Mobile Application for earthquake and tsunami early warning system which is support the Community Based Disaster Risk Reduction. This Mobile Application designed for local content of Bandar Lampung City, Lampung Province Indonesia. The research conducted by two stages: (1) to make design and to build Mobile Application for earthquake and tsunami early warning system; and (2) to deliver questionnaire a to some respondents for Mobile Application Try-Out, before and after using the mobile application. The mobile application built by this research named "Integrated Early Warning System of Lampung (Sistem Peringatan Dini Terpadu Lampung)". The results found that the "Integrated Early Warning System of Lampung" Application is also effective to give knowledge of disaster risk reduction as well as earthquake and tsunami. As conclusions, the "Integrated Early Warning System of Lampung" Application is effective to give alert and knowledge as early warning system and can be developed for national purposes.
\end{abstract}

Keywords: mobile application, earthquake, tsunami, Early Warning System, Community Based Disaster Risk Reduction

\section{INTRODUCTION}

Early Warning System (EWS) takes an important role in Disaster Risk Reduction (DRR), especially in earthquake and tsunami events. Community based DRR has emphasized the participatory to get involved in the process and goal. There were many studies investigated about how to develop DDR by policy, strategy, innovations as well as other actions [1-13, 21-23]. Several EWS [14-18] have developed to cope with earthquake and tsunami events, saving live and reducing the cost of devastated infrastructures, but there is little availability for EWS that is very user-friendly, easy to access, and have local information and content.

It is promising to fulfil the 'gap' of the need. Therefore, this research wants to develop a Mobile Application for earthquake and tsunami early warning system which is support the Community Based Disaster Risk Reduction. This Mobile Application designed for local content of Bandar Lampung City, one earthquake and tsunami prone area in southern part of Sumatera Island, Lampung Province in Indonesia.

\section{METHOD OF RESEARCH}

This research conducted in the scope of Bandar Lampung City (Fig 1) by two stages: (1) to make design and to build Mobile Application for earthquake and tsunami early warning system; and (2) to deliver questionnaire a to some respondents for Mobile Application Try-Out, before and after using the mobile application. It was emphasized that the Mobile Application is not merely an Early Warning System, but it is also an education tools of disaster risk reduction. Hence, its contents are integrated to support Community Based Disaster Risk Reduction (Community Based DRR). 


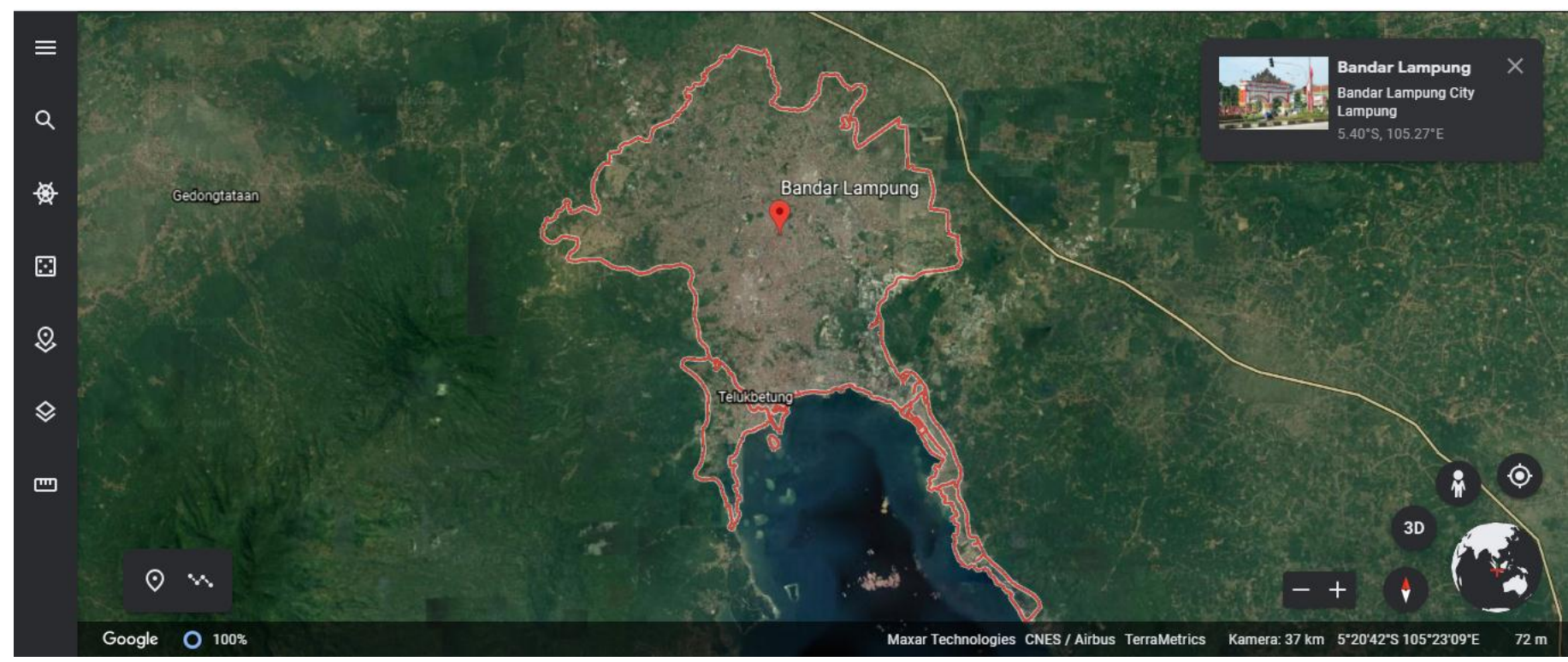

Fig 1. Sattelite visual (by Google Earth) of Bandar Lampung City, Lampung Province, Indonesia

Procedure of Mobile Application Programming is described by Fig 2 while the design of Mobile Application is explained by Fig 3 .

After the Mobile Application build, it is important to assure the user's response, especially to study their response before and after use the Mobile Application, as a tool of community based disaster risk reduction. Therefore, 103 respondents have been asked for survey as Mobile Application Try-Out. There were 53 respondents from Kangkung fishing village in Bumi Waras sub-district of Bandar Lampung City that represented marginalized community and 50 respondents from Bandar Lampung City who were educated and modern urban community. The response analysis will become significant note to improve the Mobile Application in the next research.

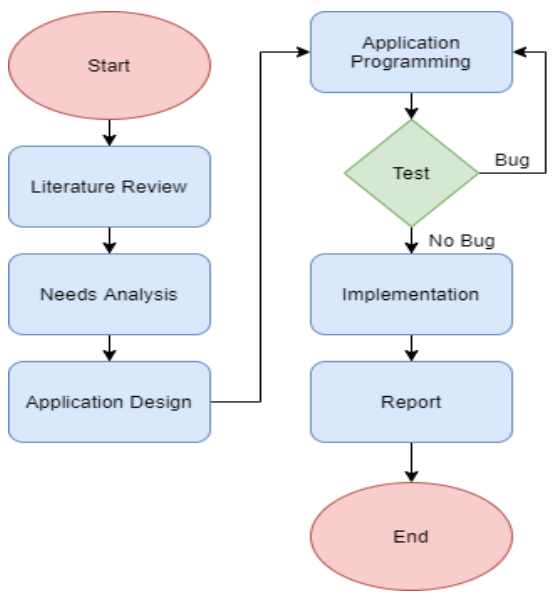

Fig 2. Mobile Application Programming [19]

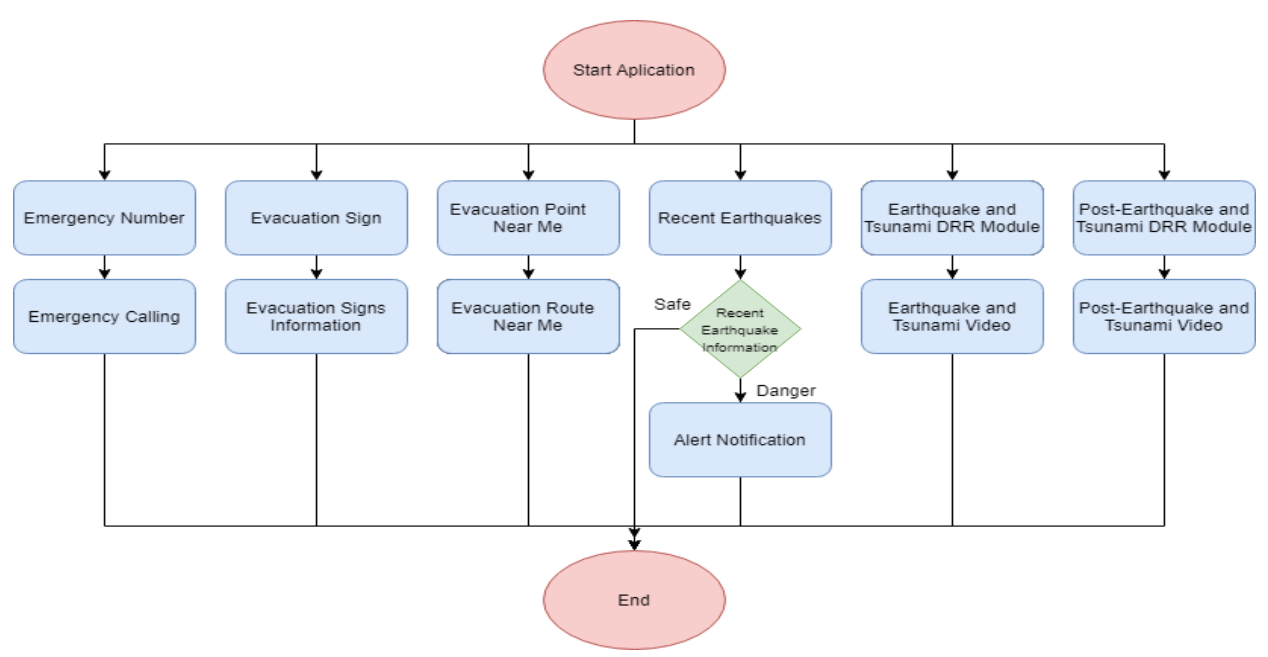

Fig 3. Design of Mobile Application [20] 


\section{RESULTS AND DISCUSSION}

\section{III.I. Mobile Application}

The mobile application this research named "Integrated Early Warning System of Lampung (Sistem Peringatan Dini Terpadu Lampung)", which was built by "Progressive Web Application" (PWA). The PWA has advantage in making the user easier to get information without downloading it from application store. It also found that by PWA, the user may also run features (i.e. emergency call, evacuation route, evacuation signs, etc.) whenever not connected to internet.

First thing to do to building the Mobile Application is to design the application with mockup software which produces pictures. The next step is programming with html, javascript, css, and php that was reformatted to become website of https://ewslampung.000webhostapp.com/. In this case, the hosting was chosen because it is free to be accessed and has SSL which are also required by PWA. To increase the performance of website, framework bootstrap was used.

The "Integrated Early Warning System of Lampung" has 6 (six) menu as described by Fig 2 and Fig3, they are: (1) Mitigation (mitigasi - Indonesia language); (2) Emergency Number (no darurat), (3) EWS/Early Warning System (SPD/Sistem Peringatan Dini); (4) Evacuation Point (titik evakuasi); (5) Evacuation Signs (rambu evakuasi); and (6) Post Earthquake (pasca gempa).

Installation of "Integrated Early Warning System of Lampung” can be conducted by accessing https://ewslampung.000webhostapp.com/ by mobile phone, laptop, or even PC (Personal Computer). Interface of the Mobile Application is described by Fig 4 for mobile phone and Fig 5 for laptop and PC.

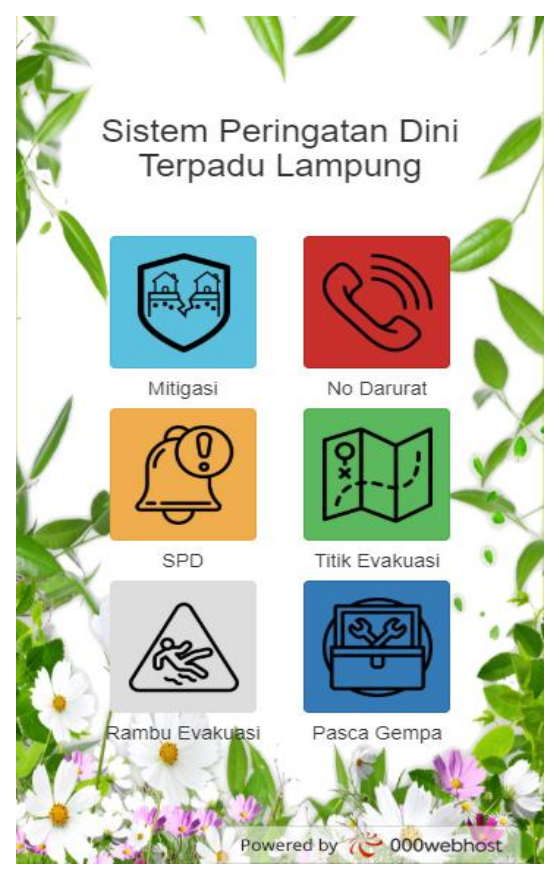

Fig 4. Interface of "Integrated Early Warning System of Lampung" for mobile phone

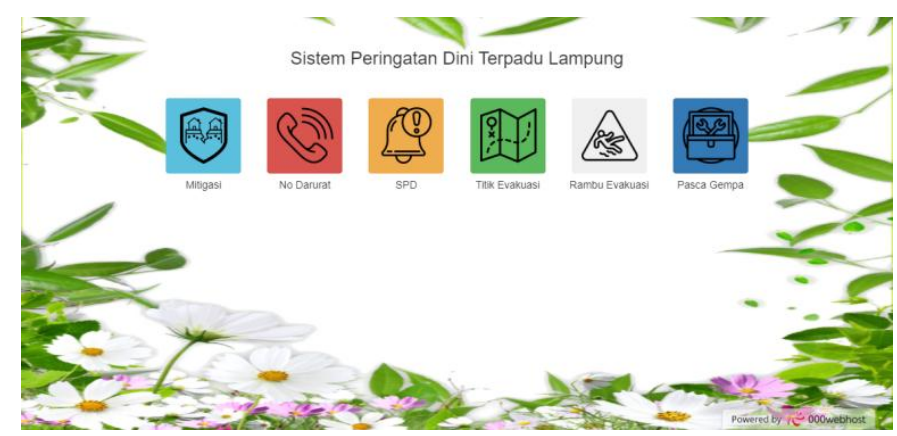

Fig 5. Interface of "Integrated Early Warning System of Lampung" for laptop and PC

On "Mitigation" menu as shown by Fig 6, several videos are provided to give education about earthquake, tsunami, and DRR (Disaster Risk Reduction). The videos are the official ones from government agencies such as National Disaster Management Agency (BNPB) and National Climatological, Metrological, Geophysical Agency (BMKG) that link to Mobile Application. One video for example linked to https://www.youtube.com/watch?v=nk38uvgEWkM.

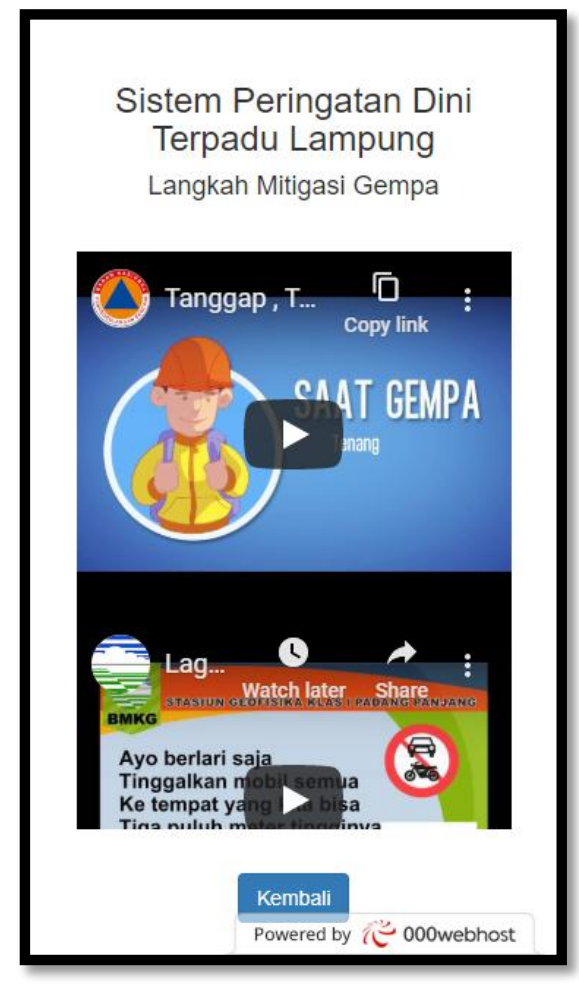

Fig 6. Interface of Menu "Mitigation"

The second menu as shown by Fig 7 is "Emergency Number". By this menu, the user may have emergency call although there is no internet connection. There are 9 (nine) emergency calls available: Police Station (110), Ambulance (118), National Search and Rescue Agency (115), Disaster Station (129), Government Electricity Office (123), Government Telephone Office (117), National Alert Station (122), Fire Department (113), and Satellite Emergency Number (112). 
International Journal of Engineering Research and Technology. ISSN 0974-3154, Volume 13, Number 10 (2020), pp. 2979-2984

(C) International Research Publication House. https://dx.doi.org/10.37624/IJERT/13.10.2020.2979-2984

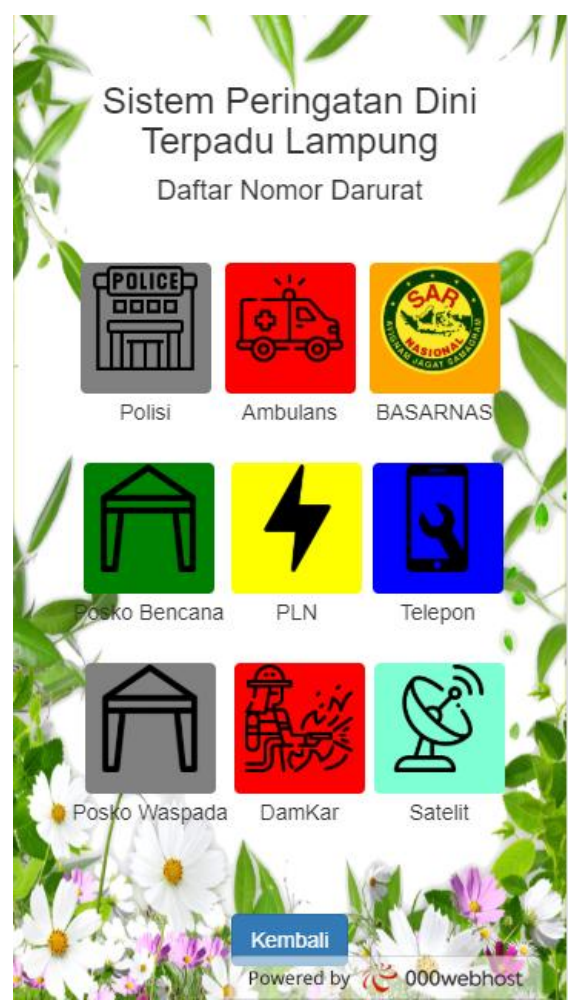

Fig 7. Interface of Menu "Emergency Number"

Early Warning System (EWS) will be the third menu as shown by Fig 8 . This menu links to official website of National Climatological, Metrological, and Geographical Agency (BMKG) which includes the official application of government as a mandatory (https://www.bmkg.go.id/ gempabumi/gempabumi-terkini. bmkg).

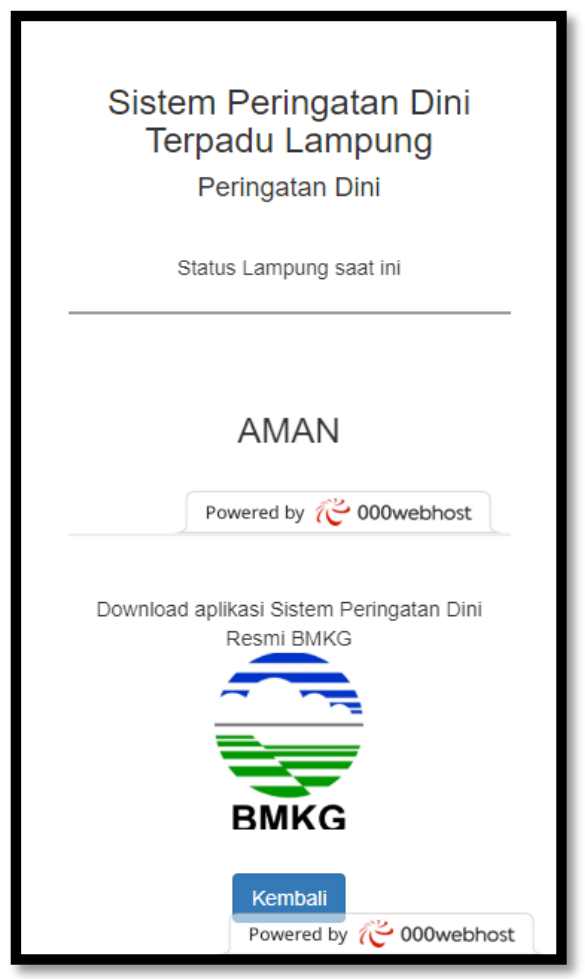

Fig 8. Interface of Menu "Early Warning System"
The "Evacuations Signs" is the fourth menu as described by Fig 9. This menu provides evacuation signs and its explanation. It will also give information about the evacuation signs available in the area.

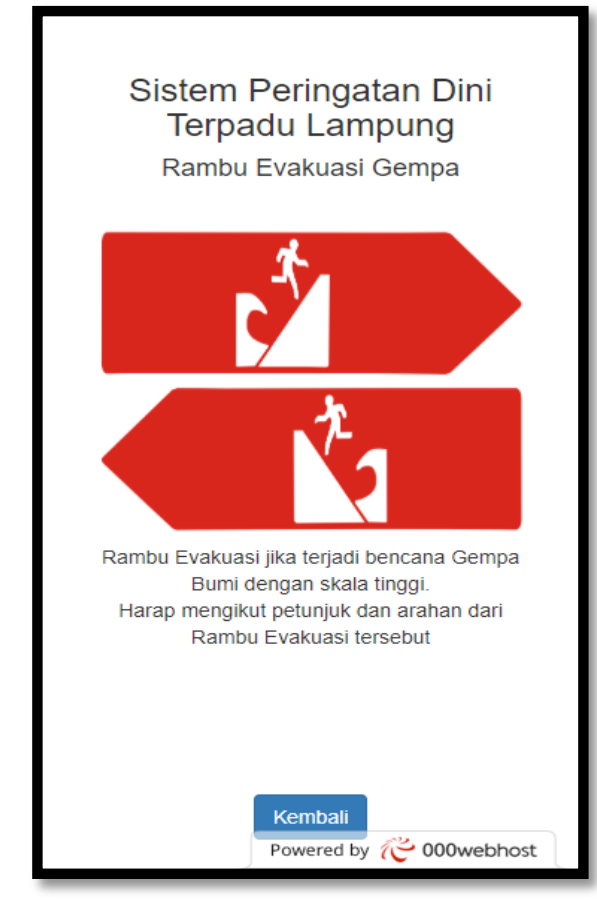

Fig 9. Interface of Menu "Evacuation Signs"

It is "Evacuations Route" as the fifth menu as described by Fig 10. The evacuation route of Lampung is available which is data of previous research [12]. There are 24 points of evacuation in the route along the coastal area which are divided into 3 (three) zones.

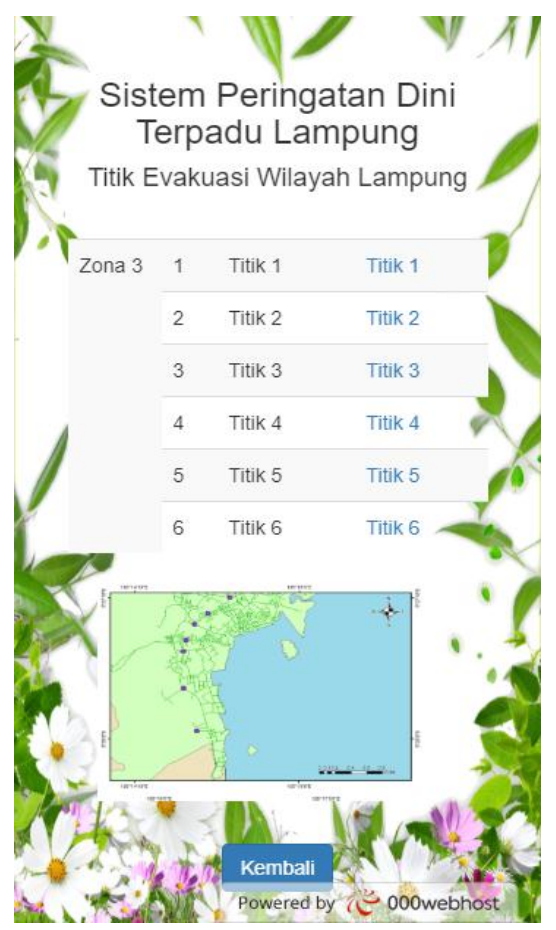

Fig 10. Interface of Menu "Evacuation Route" 
The sixth menu which is the last menu is "Post Earthquake" as described by Fig 11. This menu provides post earthquake education which give information about the things to do after the event of earthquake.

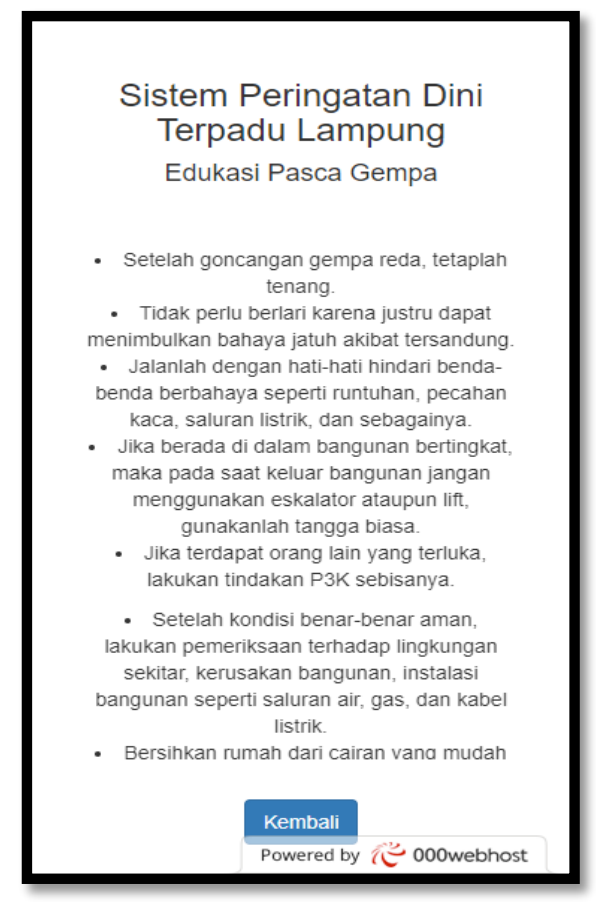

Fig 11. Interface of Menu "Post Eartquake"

\section{III.2. Survey Response}

Try-Out of "Integrated Early Warning System of Lampung" Application (Figure 12) was conducted by Pre-Survey and Post-Survey [19]. There were 103 respondents interviewed for the survey. For 53 respondents (Group I), the interview was directly conducted at Kangkung fishing village, Bumi Waras sub-district, in Bandar Lampung City [5] while for 50 respondents (Group II) in Bandar Lampung City the interview was conducted by online.

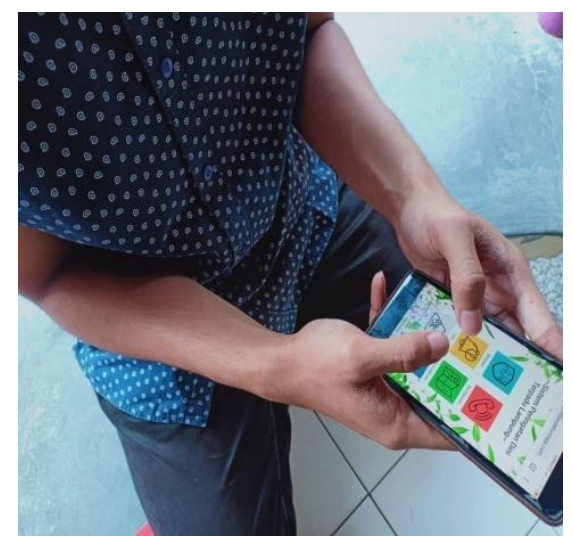

Fig 12. Try-Out of "Integrated Early Warning System of Lampung" Application

It was found that $90.6 \%$ of Group I didn't know the emergency numbers, but only $26 \%$ in Group II. On the contrary, there were only $3 \%$ of Group II that know about evacuation points nearby their place while there were $66 \%$ of Group I who know the information. All respondents of Group II have smartphone, but only $64 \%$ of Group I that have it. For the respondents who have smartphone, $62.3 \%$ of Group I have difficulties in using the application, but it was also $46 \%$ of Group II. Most respondents (60\%) from Group I and II recommended that the "Integrated Early Warning System of Lampung" Application should be widely informed and improved.

Participatory is an important aspect in community based DRR. Hence, whenever many people in the community have enough information and being alert by early warning system, the disaster risk reduction will meet the goal of saving live. It is obvious that the "Integrated Early Warning System of Lampung" Application is also effective to give knowledge of disaster risk reduction as well as earthquake and tsunami. The Mobile Application can be developed for national purposes such as provided more evacuation routes in every place, especially in earthquake and tsunami prone areas.

\section{CONCLUSIONS}

The "Integrated Early Warning System of Lampung" Application is effective to give alert and knowledge as early warning system. As promising early warning system, The "Integrated Early Warning System of Lampung" can be developed for national purposes.

\section{ACKNOWLEDGMENT}

The authors acknowledge the financial support of Ministry of Research and Technology/National Research and Innovation Agency, Republic of Indonesia, of National Research Grant on Master Thesis Research Grant Scheme in 2020 (Decree No. $26 /$ E1/KPT/2020 and No. 10/E1/Kpt/2020 and also Contract No. 082/SP2H/AMD/LTDRPM/2020, No. 008/ LL6/PGSP2H/PL.I/2020, No. 00550/H.2/LPPM/III/2020.

\section{REFERENCES}

[1] A report for the implementation of P122240Mainstreaming Disaster Risk Reduction in Indonesia Phase II Programmatic Advisory Services Analytics Building Indonesia's Resilience to Disaster: Experiences from Mainstreaming Disaster Risk Reduction in Indonesia Program. n.d.

[2] UNICEF. UNICEF and Disaster Risk Reduction. 2011.

[3] Mendis WSW, De Silva S, De Silva GHMJS. Performance and Retrofitting of Unreinforced Masonry Buildings against Natural Disasters - A Review Study. Eng J Inst Eng Sri Lanka 2014;47:71. https://doi.org/10.4038/engineer.v47i3.6896.

[4] Susilorini RMIR, Harnadi B, Wardhani DK, Angghita LJ, Febrina R, Fitra HA. From Field to Virtual: Developing Hybrid-Learning Media of Earthquake and Tsunami Disaster Resilience Strategy of Fishing Village 
Community in Bandar Lampung. E-Proceedings Int. Conf. Innov. Educ. Oppor. Challenges Southeast Asia, Semarang: Soegijapranata Catholic University; 2019, p. 267-87.

[5] Susilorini RMIR, Pamudji AK, Ismail A, Amasto AH. Alert and Response of Earthquake and Tsunami for Community Based Disaster Risk Reduction. ICOSTA 2020, Medan, Indonesia: Universitas Negeri Medan; n.d.

[6] UNISDR. Sendai Framework for Disaster Risk REduction 2015-2030. Geneva, Switzerland: 2015.

[7] Mahendra WA, Armono HD, Sambodho K. Studi Analisa Ketahanan Masyarakat Pesisir Cilacap Terhadap Bencana Tsunami. J Tek Pomits 2013.

[8] Susilorini RRMIR, Vidayanti D, Fitra HA, Santosa B. Can we adapt to tidal flooding? AIP Conf Proc 2019;2114. https://doi.org/10.1063/1.5112454.

[9] I Retno Susilorini RM, William SS, Kartikowati S, Hendri Setiawan M, Hardian LP, Kurniawan E. Masonry Walls Retrofitting with Eco-Concrete Bricks in Tidal Flooding Prone Area. vol. 13. 2020.

[10] Retno Susilorini MI, Febrina R, Fitra HA. Evaluating couple simple shear wall as low-cost masonry wall strengthening by rebound hammer test. Int J Eng Res Technol 2020;13:600-7.

[11] Retno Susilorini MI, Suryanto R, Pramana Y. Carbohydrate polymers for green multi-purpose mortar. Int J Eng Res Technol 2020;13:580-5.

[12] Febrina R, Evan DK, Afriani L, Retno RMI, Susilorini, Fitra HA. The analysis of Tsunami evacuation route based on geographic information system: A case study in the coast of Lampung Bay. IOP Conf Ser Mater Sci Eng 2020;807. https://doi.org/10.1088/1757899X/807/1/012022.

[13] Twigg J. Characteristics of a Disaster - Resilient Community. vol. 7. 2013.

[14] Rahman KM, Alam T, Chowdhury M. Location based early disaster warning and evacuation system on mobile phones using OpenStreetMap. 2012 IEEE Conf Open $\begin{array}{lll}\text { Syst } & \text { ICOS } & 2012 .\end{array}$ https://doi.org/10.1109/ICOS.2012.6417627.

[15] Sättele M, Bründl M, Straub D. Reliability and effectiveness of early warning systems for natural hazards: Concept and application to debris flow warning. Reliab Eng Syst Saf 2015;142:192-202. https://doi.org/10.1016/j.ress.2015.05.003.

[16] Gosavi A, Vishnu SS. Disaster Alert and Notification System Via Android Mobile Phone by Using Google Map. Int J Emerg Technol Adv Eng 2014;4:150-6.

[17] Haigh R, Amaratunga D, Hemachandra K. A capacity analysis framework for multi-hazard early warning in coastal communities. Procedia Eng 2018;212:1139-46. https://doi.org/10.1016/j.proeng.2018.01.147.

[18] WMO WMO. Multi-hazard Early Warning Systems: A Checklist. Outcome of the first Multi-hazard Early Warning Conference 22 to 23 May - Cancún, México 2017:20.
[19] Pamudji AK. Sistem Peringatan Dini Gempa dan Tsunami Terintegrasi Untuk Kota Siaga Bencana dengan Konsep Progressive Web App Studi Kasus: Kampung Nelayan, Kelurahan Kangkung, Kota Bandar Lampung. Soegijapranata Catholic University, 2020.

[20] Pamudji AK. Sistem Peringatan Dini Gempa dan Tsunami Terintegrasi Untuk Kota Siaga Bencana dengan Konsep Progressive Web App Sistem Peringatan Dini Gempa dan Tsunami Terintegrasi Untuk Kota Siaga Bencana dengan Konsep Progressive Web App. Soegijapranata Catholic University, 2020.

[21] Susilorini, R.M.I.R., Suwarno, D., Santosa, B., Putra, L.H., Kurniawan, E. Rebound Hammer Test result of old repaired masonry wall using premixed mortar additive in tidal flooding prone area. AIP Conference Proceedings. 2018. 1977(June). Pp. 1-6. DOI:10.1063/1.5042982.

[22] Susilorini, R.M.I.R., Santosa, B., Rejeki, V.G.S., Riangsari, M.F.D., Hananta, Y.D. The increase of compressive strength of natural polymer modified concrete with Moringa oleifera. AIP Conference Proceedings. 2017. 1818. DOI:10.1063/1.4976923.

[23] Rr. M. I. Retno Susilorini, Budi Santosa, N. Febri Satrio, R.P.B. Compressive and Splitting Tensile Strength of Polymer Modified Concrete Using Amylum and Honey. Journal of Engineering and Applied Science. 2018. 13(17). Pp. 7192-7197. DOI:http://dx.doi.org/10.3923/ jeasci.2018.7192.7197. 